\title{
РОЗВИТОК КОМУНІКАТИВНО-МОВЛЕННСВОЇ КОМПЕТЕНТНОСТІ В КОНТЕКСТІ ПРОФЕСІЙНОГО САМОЗДІЙСНЕННЯ ВИКЛАДАЧА
}

\author{
Development of Communicative and Speech Competence \\ in the Context of University Teacher's Professional Self-Fulfilment
}

\author{
Olga Korniyaka \\ Dr. Sc. in Psychology, Professor \\ G.S. Kostiuk Institute of Psychology National Academy of \\ Pedagogical Sciences of Ukraine \\ olga.korniyaka@gmail.com \\ https://orcid.org/0000-0003-1471-9238
}

\begin{abstract}
The article reveals the main features of the development of communicative-speech competence of university teachers in the process of their self-fulfilment in the space of the profession. It was found that it is the main psychological tool of the university teacher's communication and largely determines his professional self-fulfilment. In the research we represent the branched positive correlated connections of instrumental criterion of university teacher's communicative competence with significant characteristics of professional self-fulfilment. In return the connections of motivation criterion are more branched and distinct in the characteristics of internal professional than external professional self-fulfilment. The cognitive criterion of the communicative competence of lecturers has positive correlation only with internal professional self-fulfilment and its two characteristics. The most characteristic of the representatives of the scientific and pedagogical sphere is such a type of communicative (and speech) behavior, as a communicator - "circle".
\end{abstract}

Key words: communicative-speech competence, development, professional selffulfilment, communicative factors of professional self-fulfilment, communicator - "circle".

\section{Вступ Introduction}

Викладач вищої школи є типовим представником соціономічних професій, комунікативних за своїм характером. Тому успішність його професійної діяльності передбачає постійне зростання кваліфікації та професіоналізму шляхом опертя на 
професійно-комунікативну компетентність як невід’ємний засіб його комунікативної діяльності і мовленнєвого спілкування зі студентами й колегами.

У професії викладача фахове спілкування, яке реалізується через його комунікативно-мовленнєву компетентність, виступає головним засобом професійної діяльності - без нього цю діяльність неможливо виконати. Викладач має здійснювати таку професійну діяльність (комунікативно-мовленнєву за формою) у всіх сферах своєї роботи: дидактичній, науковій, виховній, методичній, організаційній тощо. Присутність діяльності професійно-мовленнєвого спілкування у всіх видах професійної діяльності цього фахівця робить пріоритетними сформованість і розвиток у системі його професійної компетентності передусім комунікативно-мовленнєвої компетентності як системи знань та вмінь. На думку дослідників (Бодальов, 1996; Ильин, 2009; Куніцина, 1991; Петровська, 2007; Самохвалова, 2012; Семиченко, 1998 та ін.), саме комунікативно-мовленнєва компетентність, зумовлена відповідними якостями особистості, значною мірою визначає ефективність педагогічної взаємодії. Це складно організоване утворення особистості виступає головним психологічним інструментом діяльності спілкування викладача. До того воно визначає великою мірою його професійне самоздійснення, що дістало підтвердження в емпіричному дослідженні.

Тому метою дослідження є з'ясування особливостей розвитку комунікативномовленнєвої компетентності викладача в процесі його самоздійснення у просторі професії.

\section{Методи та методики дослідження Methods and Techniques of the Research}

Емпіричне дослідження включало психодіагностичний і статистичний етапи, а також інформаційно-аналітичний етап 3 аналізом i синтезом, упорядкуванням i систематизацією теоретико-емпіричного матеріалу. У психодіагностичному обстеженні взяли участь (2017 - 2019 рр.) 80 респондентів - викладачів низки ЗВО України.

В емпіричному дослідженні застосовано розроблений О.М. Кокуном «Опитувальник професійного самоздійснення» (2012) для визначення загального рівня професійного самоздійснення фахівця i ступеня вираження окремих його показників. 3 метою вивчення взаємозв'язку між професійно-мовленнєвим спілкуванням i комунікативною компетентністю, яка $\epsilon$ головним інструментом діяльності викладача, застосовано методику «Діагностика комунікативної компетентності у сфері ділового спілкування» А.Г. Самохвалової, а також тести: «Вміння викладати свої думки» і «Вміння слухати». У дослідженні використовувався i психогеометричний (проективний) тест С. Деллінгер (в адаптації А.А. Алексєєва, 
Л.А. Громової), призначений для з'ясування типологічних характеристик особистості, що виявляються у спілкуванні.

\section{Результати \\ Results}

Дослідження показало, що серед найбільш виражених предикторів досягнення викладачем вищої школи високого рівня самоздійснення у професії вирішальне значення мають комунікативні чинники. Ці чинники тісно поєднуються, як показало дослідження О.М. Кокуна (2017), з показниками задоволення фахівців-соціономів змістом власної професійної діяльності й стану здоров'я. Такі результати зумовлені специфікою професійної діяльності викладача, здійснюваної у формі науковопедагогічного спілкування.

Дослідження дало також змогу встановити питому вагу впливу комунікативних детермінант на процес $\mathrm{i}$ результат досягнення викладачами професійного самоздійснення. На рівні внутрішньопрофесійного самоздійснення (що розглядається як професійне самовдосконалення, спрямоване на підвищення професійної компетентності та розвиток професійно важливих якостей) комунікативні чинники займають 64,3 \% серед інших чинників, решта відповідно - 35,7\%. Водночас частка комунікативних чинників серед прогностичних чинників впливу на зовнішньопрофесійне самоздійснення (означає досягнення значущих здобутків у різних аспектах професійної діяльності) викладачів $є$ помітно меншою і дорівнює 44\% (див. детальніше: Корніяка, 2015).

Комунікативна компетентність є, згідно з позицією А.Г. Самохвалової (2012), багаторівневою інтегративною якістю особистості, сукупністю iï мотиваційних, когнітивних, поведінкових особливостей, що зумовлює ефективне ділове спілкування. Звідси критеріями розвитку комунікативної компетентності виступають мотиваційний, когнітивний та інструментальний.

У дослідженні зафіксовано розгалужені позитивні кореляційні зв'язки інструментального критерію комунікативної компетентності цих фахівців 3 показниками професійного самоздійснення, що охоплюють майже всі його показники і мають досить виразний характер. У свою чергу, зв'язки мотиваційного критерію більш розгалужені та виразні 3 показниками внутрішньопрофесійного, ніж зовнішньопрофесійного, самоздійснення. Когнітивний критерій комунікативної компетентності викладачів вищої школи має позитивну кореляцію лише 3 внутрішньопрофесійним рівнем самоздійснення та двома його показниками: «потреба у професійному вдосконаленні» і «постійна постановка нових професійних цілей». 
Тим часом стосовно вміння викладати свої думки, що є однією з ключових складових комунікативно-мовленнєвої компетентності, спостерігається лише тенденція до позитивної кореляції з внутрішньопрофесійним самоздійсненням, проте зафіксовано позитивний кореляційний зв’язок з такими його складовими, як «потреба у професійному вдосконаленні», «наявність проекту власного професійного розвитку» $\mathrm{i}$ «постійна постановка нових професійних цілей». До того існує позитивний кореляційний зв'язок між вмінням слухати, яке так само є важливою структурною складовою комунікативно-мовленнєвої компетентності, і показниками «потреба у професійному вдосконаленні» (внутрішньопрофесійне самоздійснення) та «розкриття особистісного потенціалу i здібностей у професії» - зовнішньо-професійне самоздійснення (Корніяка, 2018).

Поза тим з метою з'ясування типологічних характеристик особистості фахівця, що виявляються у спілкуванні, в дослідженні використовувався також nсихогеометричний тест С. Деллінгер. У плані інтерпретаційних можливостей цього тесту зауважимо про таке: обрана особистістю при тестуванні геометрична фігура (квадрат, трикутник, коло, зигзаг, прямокутник) виступає як основна фігура, або суб'єктивна форма, даючи змогу визначити головні, домінувальні, риси характеру й особливості поведінки особистості у спілкуванні.

В результаті психодіагностичного обстеження викладачів (n=53) отримано їх комунікативні характеристики у таких суб'єктивних формах: комунікант-«квадрат» (17\%); комунікант-«трикутник» (20,8\%); комунікант-«коло» (41,5\%); комунікант«зигзаг» (7,5\%); комунікант-«прямокутник» $(13,2 \%)$. Як бачимо, найбільш характерним для представників науково-педагогічної сфери $\epsilon$ такий тип комунікативної поведінки, як комунікант-«коло». Людині з цією суб'єктивною формою комунікації властиві освіченість, інтуїтивність, інтегративність, мозаїчність, а також послідовна дедукція. Це найкращий комунікатор серед виокремлених п'яти суб'єктивних форм на тій підставі, що він $є$ добрим слухачем, йому притаманна висока чутливість, розвинена емпатійність - здатність співпереживати, співчувати, емоційно відгукуватися на переживання іншої людини. Мовлення у комуніканта«кола» в міжособистісному спілкуванні зазвичай непослідовне і нерідко не стосується безпосередньо справи. Опрацювання інформації здійснюється ним не у послідовному форматі, а скоріше мозаїчно, з пропуском окремих ланок. Це не означає, що «кола» не в ладах з логікою, просто формалізми не дістають у них пріоритету у вирішенні життєвих проблем. Головні риси їх стилю мислення - орієнтація на суб'єктивні чинники проблеми (цінності, оцінки, почуття і т.п.) і прагнення знайти спільне навіть у протилежних точках зору (Психологический журнал, 2014). 
Дослідження показало, що сформованість комунікативної (соціальної) складової виступає однією з найважливіших складових професійного здоров’я цього фахівця, а відтак, наявності у нього реальної можливості для подальшого професійного самоздійснення. Вона виявляється у здатності фахівця - завдяки комунікативно-мовленнєвій грамотності - налагоджувати продуктивні ділові та міжособистісні взаємини з оточенням, забезпечувати комфортність свого самопочуття у міжособистісній взаємодії.

\section{Висновки Conclusions}

Комунікативно-мовленнєва компетентність відіграє важливу роль у самоздійсненні фахівців науково-педагогічного профілю, становленні та розвитку їх професійної компетентності, що реалізується у здійснюваній ними науково-педагогічній діяльності.

Науково-педагогічна діяльність викладача - це емоційно насичена «інтелектуальна творча праця», що здійснюється у формі мовленнєвої комунікації. «Працюючи» 3 внутрішнім світом іншої людини, цей фахівець повинен повсякчас підтримувати довіру до себе як до суб'єкта комунікативної діяльності через постійне збагачення своєї комунікативно-мовленнєвої компетентності, набуття майстерності й гнучкості у педагогічному спілкуванні.

\section{Література References}

Ильин, Е.П. (2009). Психология общения и межличностных отношений. Санкт-Петербург: Питер.

Кокун, О.М. (2015). Психофізіологічні закономірності професійного самоздійснення особистості: концептуально-емпіричні основи. Актуальні проблеми психології: зб. наук. праць Інституту психології імені Г.С. Костюка НАПН України. Т. V: Психофізіологія. Психологія праџі. Експериментальна психологія. 15, 60-71.

Корніяка, О.М. (2015). Психофізіологічні закономірності професійного самоздійснення викладачів вищої школи. О. М. Кокун (Ред.), Психофізіологічні закономірності професійного самоздійснення особистості (с. 157-170). Київ: Педагогічна думка. Retrieved from https://lib.iitta.gov.ua/10038/

Корніяка, О.М. (2018). Комунікативні чинники професійного самоздійснення викладача вищої школи. Psycholinguistics, 23(1), 139-159.

Психологический журнал. 2014. №10 (Раздел: Тесты). Retrieved from https://www.hrm21.ru/rus/tests/test1/geomtest/

Самохвалова, А.Г. (2012). Деловое общзение: секреты эффективных коммуникаиий: учебное пособие. Санкт-Петербург: Речь. 